\title{
PENGARUH PERBANDINGAN TEPUNG BERAS MERAH PREGELATINISASI DENGAN TERIGU TERHADAP KARAKTERISTIK CRACKERS
}

\section{THE EFFECT OF THE COMPARISON OF PREGELATINIZED RED RICE FLOUR WITH THE WHEAT FLOUR ON THE CHARACTERISTICS OF CRACKERS}

\author{
I Gusti Ayu Atyantha Danawati ${ }^{1)}$, A.A.G.N. Anom Jambe ${ }^{2)}$, I Gusti Ayu Ekawati ${ }^{2)}$ \\ ${ }^{1}$ Mahasiswa Program Studi Imu dan Teknologi Pangan, Fakultas Teknologi Pertanian, Unud \\ ${ }^{2}$ Dosen Program Studi Imu dan Teknologi Pangan, Fakultas Teknologi Pertanian, Unud \\ Kampus Bukit Jimbaran, Badung-Bali
}

\begin{abstract}
The purpose of this research to find the effect of the comparison of pregelatinization red rice flour with wheat flour on the characteristics of crackers and also to find the best ratio of red rice flour with wheat flour to the characteristics of crackers. This study used a Compeletely Randomized Design (CRD) with a comparison of red rice flour pregelatinization with wheat flour consisting of 6 treatment namely $0 \%: 100 \% ; 10 \%: 90 \% ; 20 \%: 80 \% ; 30 \%: 70 \% ; 40 \%: 60 \% ; 50 \%: 50 \%$. The treatment repeated 3 times, so that resulting in 18 experimental units. The resulting data is analyzed with variance and if the inter treatment effect on the observed variance, then continue with Duncan test. The result showed that pregelatinization red rice flour and wheat flour significantly affected to water content, protein content, total phenol, and antioxidant activity in crackers and had no significant effect on ash content. The comparison ratio of $50 \%$ pregelatinazation red rice flour with $50 \%$ wheat flour produces crackers with the best characteristics, namely: water content of $1.15 \%$, ash content of $1.73 \%$, $10.30 \%$ protein content, total phenol $158.83 \%$ and $45.17 \%$ antioxidant activity colour very like, texture crispy, overall liked, aroma,taste and overall acceptance like.
\end{abstract}

Keywords : crackers, red rice, pregelatinized, wheat flour

\section{PENDAHULUAN}

Masyarakat Indonesia memiliki kebiasaan untuk mengkonsumsi makanan ringan sebagai camilan/snack. Crackers merupakan salah satu pilihan yang sering dikonsumsi sebagai camilan/snack. Hal ini dapat dilihat dengan tersedianya crackers hampir di semua toko makanan ringan baik di perkotaan maupun warung-warung kecil dipelosok desa. Crackers adalah produk makanan kering yang dibuat dengan memanggang adonan yang mengandung bahan dasar terigu, lemak, dan bahan pengembang dengan tanpa penambahan bahanmakanan tambahan lain yang diijinkan.

Crackers adalah biskuit yang terbuat dari terigu, lemak, dan garam yang difermentasi dengan yeast serta adonan dibuat berlapis-lapis, kemudian dipotong dan dipanggang (Manley,1983).
Bahan utama dari biscuit crackers adalah terigu yang berasal dari gandum. Indonesia saat ini menduduki peringkat kedua import gandum terbesar di dunia (Aptindo, 2016). Oleh karena itu perlu adanya upaya mengurangi ketergantungan terhadap penggunaan terigu. Salah satu cara untuk mengurangi kebutuhan terigu maka dapat dilakukan dengan mengembangkan produk lokal. Salah satu jenis produk lokal yang potensial sebagai pengganti terigu adalah beras merah.

Beras merah mengandung karbohidrat khususnya pati yang tinggi yaitu $77 \%, 7 \%$ protein $0,4 \%$ lemak, $0,4 \%$ dan serat kasar (Juliano and Bechtel,1985). Beras merah merupakan bahan pangan pokok lain di Indonesia selain beras putih yang mempunyai nutrisi yang cukup tinggi, yaitu mengandung antosianin $0,00247 \mathrm{mg} \mathrm{GAE} / \mathrm{g}$ yang berfungsi

\footnotetext{
*Korespondensi Penulis:

E-mail: gstatyantha@gmail.com ${ }^{1)}$
} 
sebagai antioksidan (Suliartini, dkk., 2011).

Beras merah dikategorikan sebagai beras pecah kulit karena gabah dari tanaman padi hanya diberi perlakuan pengupasan pada bagian kulit luar (hull), namun tidak dilakukan penyosohan dan penggilingan lebih lanjut.Salah satu bentuk olahan beras merah paling sederhana adalah tepung beras merah. tepung beras merah mempunyai kelebihan yaitu memudahan penyimpanan dan penyiapan sebagai bahan baku suatu produk serta mempunyai daya tahan yang relatif lebih tinggi dibandingkan bentuk bijinya (Susanto dan suseto,1994). Menurut Tamdani, (2012) penggunaan tepung beras merah pada pembuatan cookies dapat menyebabkan munculnya rasa berpati pada cookies, hal tersebut disebabkan oleh sedikitnya jumlah air pada adonan cookies, sehingga pati tidak tergelatinisasi pada saat pemanggangan. Upaya yang dilakukan untuk mencegah rasa berpati tersebut adalah dengan melakukan pregelatinisasi pada tepung beras merah sebelum digunakan. Proses pregelatinisasi dapat memperbaiki sifat fungsional dari tepung beras merah, seperti daya serap air, swelling power, dan indeks kelarutan. Berdasarkan uraian tersebut diatas maka dilakukan penelitian mengenai pengaruh perbandingan tepung beras merah pregelatinisasi dengan terigu terhadap karakteristik crackers.

\section{METODE PENELITIAN}

Tempat dan Waktu

Penelitian ini dilaksanakan di

Laboratorium Pengolahan Pangan, Laboratorium Analisis Pangan dan Laboratorium Rekayasa Proses dan Pengendalian Mutu, Fakultas Teknologi Pertanian, Universitas Udayana. Waktu pelaksanaan mulai bulan Agustus sampai dengan bulan Oktober 2018.

\section{Bahan dan Alat}

Bahan - bahan yang digunakan dalam melaksanakan penelitian ini terdiri dari bahan baku, bahan tambahan, dan bahan kimia. Bahan baku yang digunakan yaitu terigu dengan merek Segitiga Biru dan beras merah yang diperoleh dari pasar tradisional. gula halus, garam (Cap Jago), minyak sayur, baking soda, ragi instan (fermipan), yang didapatkan dari toko bahan kue UD. Fenny jalan Kartini
No.83, Dauh Puri Kaja, Denpasar Utara. Bahan kimia yag digunakan dalam melakukan analisis meliputi $\mathrm{H}_{2} \mathrm{SO}_{4}, \mathrm{NaOH}, \mathrm{HCl}$, tablet Kjeldahl, asam borat, dan indikator PP, methanol, DPPH, follin, $\mathrm{Na}_{2} \mathrm{CO}_{3}$,

Alat-alat yang digunakan adalah waskom, loyang, alat penggilingan, timbagan analitik (Shimadzu), timbangan, oven(Memmert), kompor gas, oven, ayakan 80 mesh, kertas saring, erlenmeyer, cawan porselin, tabung reaksi, batang pengaduk, eksikator, corong, pipet tetes, labu takar, buret, muffle, pendingin balik, destilator, spektrofotometer, gelas ukur, gelas beker, pipet volume, labu kjeldahl, soxhlet, waterbath, dan peralatan analisis kadar abu. Selain itu untuk evaluasi sensoris produk, alat yang digunakan adalah piring kertas dan sendok.

\section{Rancangan Percobaan}

Rancangan penelitian yang digunakan dalam penelitian ini adalah Rancangan Acak Lengkap (RAL) dengan perlakuan perbandingan tepung beras merah pregelatinisasi dengan terigu yaitu: $\mathrm{P} 0(0 \%$ : $100 \%), \mathrm{P} 1(10 \%$ : $90 \%), \mathrm{P} 2(20 \%: 80 \%)$, $\mathrm{P} 3(30 \%: 70 \%), \mathrm{P} 4(40 \%: 60 \%), \mathrm{P} 5(50 \%$ : $50 \%$ ). Masing - masing perlakuan diulang sebanyak 3 kali, sehingga didapat 18 unit percobaan. Data yang diperoleh dari hasil penelitian dianalisis dengan sidik ragam (ANOVA) dan apabila perlakuan berpengaruh terhadap variabel maka dilanjutkan dengan uji Duncan's Multiple Range Test (DMRT) (Gomez dan Gomez, 1995).

\section{Pelaksanaan Penelitian}

Persiapan bahan-bahan yang digunakan dalam pembuatan crackers yaitu tepung beras merah pregelatinisasi, terigu, minyak,gula bubuk, baking soda, ragi, air, dan garam. Bahan yang digunakan kemudian ditimbang sesuai dengan formulasi seperti terlihat pada Tabel 1.

\section{Pembuatan Tepung Beras Merah}

Proses pembuatan tepung beras merah adalah sebagai berikut : beras merah yang disortasi dan dicuci dengan menggunakan air mengalir, selanjutnya direndam dengan mengguunakan air selama 15 menit, kemudian ditiriskan dan dikeringkan menggunakan sinar matahari sampai airnya hilang (Yessica 2013), lalu dihancurkan dengan menggunakan 
penggilingan. Tepung beras merah selanjutnya diayak menggunakan ayakan berukuran 80 mesh. Diagram alir pembuatan tepung beras merah dapat dilihat pada Gambar 1.

Tabel 1.Formulasi Crackers dengan perbandingan tepung beras merah pregelatinisasi dan terigu.

\begin{tabular}{llcccccc}
\hline \multirow{2}{*}{ No Komposisi Bahan } & \multicolumn{7}{c}{ Perlakuan } \\
\cline { 3 - 7 } & & P0 & P1 & P2 & P3 & P4 & P5 \\
\hline 1. & Tepung beras merah pregelatinisasi (\%) & 0 & 10 & 20 & 30 & 40 & 50 \\
2. & Terigu (\%) & 100 & 90 & 80 & 70 & 60 & 50 \\
3. & Minyak Sayur (\%) & 60 & 60 & 60 & 60 & 60 & 60 \\
4. & Gula halus (\%) & 2,5 & 2,5 & 2,5 & 2,5 & 2,5 & 2,5 \\
5. & Garam (\%) & 6 & 6 & 6 & 6 & 6 & 6 \\
6. & Ragi(\%) & 2,5 & 2,5 & 2,5 & 2,5 & 2,5 & 2,5 \\
7. & Baking soda (\%) & 1 & 1 & 1 & 1 & 1 & 1 \\
8. & Air (\%) & 60 & 60 & 60 & 60 & 60 & 60 \\
\hline
\end{tabular}

Ket : Persentase berdasarkan jumlah terigu dan tepung beras pregelatinisasi (100g)

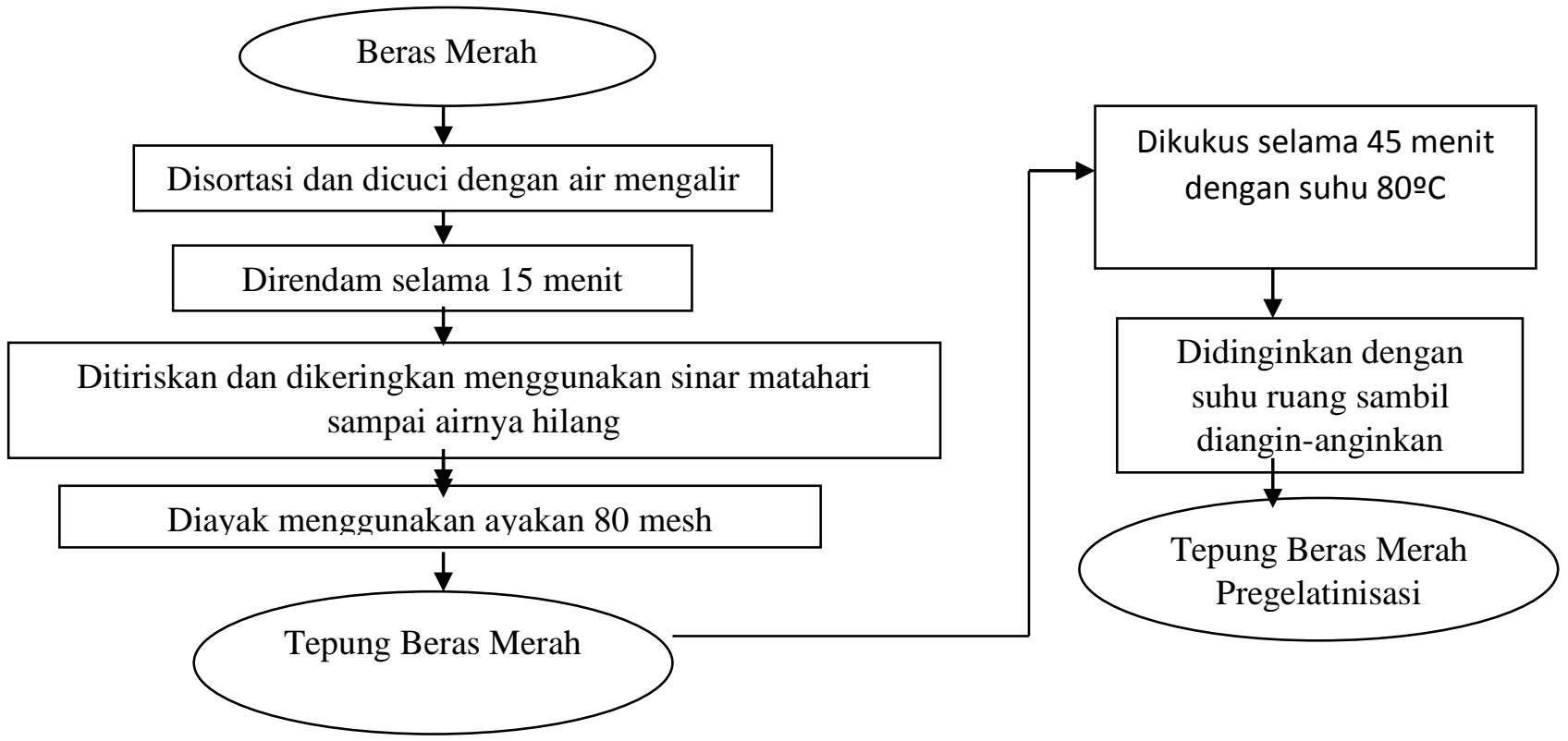

Gambar. 1 Diagram alir pembuatan tepung beras merah dan pembuatan tepung beras merah pregelatinisasi

\section{Pembuatan Tepung Pregelatinisasi Beras Merah}

Pembuatan tepung beras merah pregelatinisasi. dilakukan dengan mengukus tepung beras merah pada suhu $80^{\circ} \mathrm{C}$ selama 45 Proses Pembuatan Crackers

Proses pembuatan crackers menurut Departemen Perindustrian (1990) yang dimodifikasi, yaitu tepung beras merah pregelatinisasi, terigu, dicampur sesuai perlakuan dan ditambahkan baking soda, lalu diayak. Ragi dilarutkan dengan $20 \mathrm{ml}$ air di diamkan selama 20 menit bertujuan untuk mengaktifkan ragi, kemudian ditambahkan gula, garam, dan sisa air, sehingga membentuk larutan. Selanjutnya ditambahkan minyak menit selanjutnya didinginkan pada suhu ruang sambil di angin-anginkan sehingga menghasilkan tepung beras merah pregelatinisasi (Tamdani, 2012).

sayur campuran tepung beras merah pragelatinisasi, terigu. Adonan diuleni hingga menjadi adonan yang kalis. Adonan kemudian difermentasi selama 30 menit, pada suhu ruang. Setelah 30 menit adonan digiling membentuk lembaran dan diatur ketebalannya sekitar $1 / 2 \mathrm{~cm}$. Pada 1/2 bagian lembaran ditaburi bahan pengisi (dust filling) dengan formula $50 \mathrm{~g}$ tepung beras merah pregelatinisasi, 0,4g baking soda dan $0,5 \mathrm{~g}$ garam yang disebar pada $1 / 2$ bagian lembaran. 
Setelah itu $1 / 2$ bagian lembaran lainnya dilipat hingga menutupi permukaan lembaran yang ada bahan pengisi dan dipotong dengan ukuran seragam menjadi $3 \times 5 \mathrm{~cm}$. Setelah dipotong adonan diletakan dalam loyang dan di lakukan fermentasi tahap 2 selama 10 menit

\section{HASIL DAN PEMBAHASAN}

\section{Kadar Air}

Hasil sidik ragam menunjukkan bahwa perlakuan perbandingan tepung beras merah pregelatinisasi dengan terigu berpengaruh nyata $(\mathrm{P}<0,05)$ terhadap kadar air crackers yang dihasilkan. Berdasarkan Tabel 3, nilai rata-rata kadar air crackers berkisar antara $1,15 \%$ sampai dengan $3,44 \%$. Nilai rata-rata kadar air tertinggi crackers pada perlakuan $\mathrm{P} 0$ yaitu $3,44 \%$ sedangkan nilai rata-rata terendah kadar air crackers diperoleh pada perlakuan P5 yaitu $1,15 \%$ dan tidak berbeda dengan perlakuan P3, P4, P5.

Penurunan kadar air crackers dengan semakin meningkatnya penambahan tepung beras merah pregelatinisasi disebabkan karena tepung beras merah pregelatinisasi memiliki kadar air lebih rendah dibandingkan terigu. Berdasarkan hasil analisis bahan baku (Tabel 2), Menurut standar mutu SNI kadar air crackers maksimal $5,00 \%$ jadi crackers pada suhu ruang sebelum dimasukan ke oven. Setelah 10 menit adonan di oven pada suhu $130^{\circ} \mathrm{C}$ selama $10-15$ menit. Crackers yang sudah matang dikeluarkan dari loyang dan didinginkan. dari hasil penelitian memenuhi standar SNI.

\section{Kadar Abu}

Hasil sidik ragam menunjukkan bahwa perlakuan perbandingan tepung beras merah pregelatinisasi dengan terigu berpengaruh tidak nyata $(\mathrm{P}>0,05)$ terhadap kadar abu crackers dihasilkan (Tabel 3). Nilai rata-rata kadar abu pada crackers tepung beras merah pregelatinisasi dengan terigu berkisar antara $1,34 \%$ sampai dengan $1,73 \%$. Nilai rata-rata kadar abu tertinggi crackers diperoleh pada perlakuan P5 yaitu 1,73\% sedangkan nilai rata-rata terendah kadar abu crackers di peroleh pada perlakuan P0 yaitu $1,34 \%$. Menurut standar mutu SNI kadar abu crackers maksimal $2,00 \%$ jadi crackers dari hasil penelitian memenuhi standar SNI.

Hasil analisis bahan baku seperti kadar air, kadar abu, dan kadar protein tepung beras merah pregelatinisasi dan terigu dapat dilihat pada Tabel 2.

Tabel 2. Nilai Rata-rata Kadar Air, Kadar Abu dan Kadar Protein Pada Crackers dengan Perlakuan Perbandingan Tepung Beras Merah Pregelatinisasi dan Terigu.

\begin{tabular}{cccc}
\hline Perlakuan & Kadar Air (\%) & Kadar Abu(\%) & Kadar Protein $(\%)$ \\
\hline P0 & $3.44 \pm 0,32 \mathrm{a}$ & $1.34 \pm 0,14 \mathrm{a}$ & $18,82 \pm 0,52 \mathrm{a}$ \\
P1 & $2,62 \pm 0,47 \mathrm{~b}$ & $1.36 \pm 0,23 \mathrm{a}$ & $16,78 \pm 0,77 \mathrm{~b}$ \\
P2 & $1,83 \pm 0,37 \mathrm{c}$ & $1.48 \pm 0,21 \mathrm{a}$ & $15,09 \pm 0,78 \mathrm{c}$ \\
P3 & $1,38 \pm 0,28 \mathrm{c}$ & $1.51 \pm 0,20 \mathrm{a}$ & $14,38 \pm 086 \mathrm{c}$ \\
P4 & $1,26 \pm 0,49 \mathrm{c}$ & $1.53 \pm 0,32 \mathrm{a}$ & $12,46 \pm 0,90 \mathrm{~d}$ \\
P5 & $1,15 \pm 0,30 \mathrm{c}$ & $1.73 \pm 0,25 \mathrm{a}$ & $10,26 \pm 0,26 \mathrm{e}$ \\
\hline
\end{tabular}

Tabel 3. Hasil Analisis Kadar Air, Kadar Abu, Kadar Protein, Tepung Beras Merah Pregelatinisasi dan Terigu.

\begin{tabular}{ccc}
\hline Uji & $\begin{array}{c}\text { Tepung Beras Merah } \\
\text { Pregelatinisasi }(\%)\end{array}$ & Terigu (\%) \\
\hline Kadar Air & $8,47 \%$ & $10,12 \%$ \\
Kadar Abu & $0,75 \%$ & $0,55 \%$ \\
Kadar Protein & 7,20 & $10,20 \%$ \\
\hline
\end{tabular}




\section{Kadar Protein}

Hasil sidik ragam menunjukkan bahwa perlakuan perbandingan tepung beras merah pregelatinisasi dengan terigu berpengaruh nyata $(\mathrm{P}<0,05)$ terhadap kadar protein crackers. Berdasarkan Tabel 3 nilai rata-rata kadar protein crackers berkisar antara 10,26\% sampai dengan $18,82 \%$. Nilai rata-rata kadar protein tertinggi diperoleh pada perlakuan P0 yaitu $18,82 \%$ sedangkan nilai rata-rata terendah di peroleh pada perlakuan P5 yaitu $10,26 \%$.

Semakin meningkat penambahan tepung beras merah pregelatinisasi pada pembuatan crackers maka kadar protein crackers semakin menurun, hal ini disebabkan karena kadar protein tepung beras merah pregelatinisasi lebih rendah dibandingkan kadar protein terigu. Menurut standar mutu SNI kadar protein crackers minimal $8,00 \%$ jadi crackers dari hasil penelitian memenuhi standar SNI.

Berdasarkan hasil analisis bahan baku (Tabel 7), kadar protein tepung beras merah pregelatinisasi sebesar $7,20 \%$, dan kadar protein terigu sebesar 10,20\% .

\section{Total Fenol}

Hasil sidik ragam menunjukkan bahwa perlakuan perbandingan tepung beras merah pregelatinisasi dengan terigu berpengaruh nyata $(\mathrm{P}<0,05)$ terhadap total fenol pada crackers. Tabel 4 menunjukkan nilai terendah sampai tertinggi total fenol pada crackers berkisar antara 75,95 GAE/g sampai dengan 158,83 GAE/g. Nilai pada perlakuan P5 yaitu 158,83 GAE/g sedangkan nilai pada perlakuan P0 yaitu 75,95 GAE/g.

Semakin meningkat penambahan tepung beras merah pregelatinisasi pada pembuatan crackers maka total fenol pada crackers semakin meningkat. Kandungan senyawa fenol pada tepung beras merah komersial 390,469 GAE/g (Karina, 2017). Senyawa fenolik yang ada dalam tepung beras merah antara lain asam galat, asam protokatekuat, asam p-hidroksi benzoat, guaiacol, p-cresol, ocresol, dan 3.5-silanol (Vichapong et al., 2010). Analisis total fenol dilakukan untuk mengetahui kadar senyawa bioaktif, yang berpotensi sebagai antioksidan.

\section{Aktivitas Antioksidan}

Hasil sidik ragam menunjukkan bahwa perlakuan perbandingan tepung beras merah pregelatinisasi dengan terigu berpengaruh nyata $(\mathrm{P}<0,05)$ terhadap aktivitas antioksidan pada crackers. Tabel 4 menunjukkan nilai terendah hingga tertinggi aktivitas antioksidan pada crackers berkisar antara $11,49 \%$ sampai dengan $45,17 \%$. Nilai rata-rata aktivitas antioksidan terendah P0 yaitu $11.49 \%$ diperoleh pada perlakuan sedangkan nilai rata-rata tertinggi di peroleh pada perlakuan P5 yaitu 45,17\% .

Semakin meningkat penambahan tepung beras merah pregelatinisasi pada pembuatan crackers maka aktivitas antioksidan pada crackers semakin meningkat, Terjadinya kenaikan aktivitas antioksidan pada crackers disebabkan karena tepung beras merah pregelatinisasi mengandung antosianin yang bersifat sebagai antioksidan. Menurut Paini (2014) beras merah mengandung antosianin sebesar 0,00247 mg GAE/g. Selain antosianan senyawa fenol yang terkandung pada beras merah, juga dapat berfungsi sebagai antioksidan, hal ini terlihat dari hasil analisis total fenol crackers yang berkorelasi positif dengan aktivitas antioksidan.

Evaluasi Sifat Sensoris

Evaluasi sifat sensoris crackers dilakukan dengan uji hedonik terhadap warna, aroma, tekstur, rasa dan penerimaan keseluruhan. Uji skoring dilakukan terhadap tekstur crackers. Nilai rata-rata uji hedonik terhadap warna, aroma, tekstur, rasa dan penerimaan keseluruhan crackers dapat dilihat pada Tabel 5. Nilai rata-rata uji skoring terhadap tekstur crackers dapat dilihat pada Tabel 6. 
Tabel 4. Nilai Rata-rata Total Fenol, dan Aktivitas Antioksidan Pada Crackers Dengan Perlakuaan Perbandingan Tepung Beras Merah Pregelatinisasi Dan Terigu.

\begin{tabular}{ccc}
\hline Perlakuan & Total Fenol $(\mathrm{GAE} / \mathrm{g})$ & Aktivitas Antioksidan $\%$ \\
\hline P0 & $75,95 \pm 0,00 \mathrm{f}$ & $11,49 \pm 0,00 \mathrm{e}$ \\
P1 & $151,59 \pm 0,59 \mathrm{e}$ & $38,11 \pm 0,84 \mathrm{~d}$ \\
P2 & $153,75 \pm 0,83 \mathrm{~d}$ & $41,40 \pm 0,34 \mathrm{c}$ \\
P3 & $154,97 \pm 0,53 \mathrm{c}$ & $42,25 \pm 0,52 \mathrm{bc}$ \\
P4 & $157,13 \pm 0,79 \mathrm{~b}$ & $43,09 \pm 0,47 \mathrm{~b}$ \\
P5 & $158,83 \pm 0,34 \mathrm{a}$ & $45,17 \pm 0,69 \mathrm{a}$ \\
\hline
\end{tabular}

Keterangan : Nilai rata - rata yang diikuti oleh huruf yang berbeda pada kolom yang sama menunjukkan berbeda nyata $(\alpha=0,05)$

\section{Evaluasi Sifat Sensoris}

Evaluasi sifat sensoris crackers dilakukan dengan uji hedonik terhadap warna, aroma, tekstur, rasa dan penerimaan keseluruhan. Uji skoring dilakukan terhadap tekstur crackers. Nilai rata-rata uji hedonik terhadap warna, aroma, tekstur, rasa dan penerimaan keseluruhan crackers dapat dilihat pada Tabel 5. Nilai rata-rata uji skoring terhadap tekstur crackers dapat dilihat pada Tabel 6.

\section{Warna}

Hasil sidik ragam menunjukkan bahwa penambahan tepung beras merah sangat berpengaruh nyata $(\mathrm{P}<0,01)$ terhadap warna crackers. Tabel 5 menunjukkan bahwa nilai rata-rata kesukaan panelis terhadap warna crackers berkisar antara 5,07 (agak suka) sampai dengan 6,73 (sangat suka). Nilai rata-rata terendah terhadap warna crackers diperoleh pada perlakuan P0 yaitu 5,07 (agak suka) sedangkan nilai rata-rata tertinggi di peroleh pada perlakuan P5 yaitu 6.73 (sangat suk)a panelis. Hal ini disebabkan karena dengan penambahan tepung beras merah pregelatinisasi menimbulkan terjadinya perubahan warna, yang disebabkan oleh beras merah. Menurut Winarno (2002) warna merupakan komponen yang sangat penting untuk menentukan kualitas atau derajat penerimaan suatu bahan pangan. Suatu bahan pangan meskipun dinilai enak dan teksturnya sangat baik, tetapi memiliki warna yang tidak menarik maka bahan tersebut tidak akan dikonsumsi. Penentuan mutu suatu bahan pangan pada umumnya tergantung pada warna karena warna tampil terlebih dahulu.

\section{Aroma}

Hasil sidik ragam menunjukkan bahwa penambahan tepung beras merah pregelatinisasi sangat berpengaruh nyata terhadap aroma crackers $(\mathrm{P}<0,01)$. Tabel 5. menunjukkan bahwa nilai rata-rata kesukaan panelis terhadap aroma berkisar antara 5,67(disukai) sampai dengan 6,40 (disukai). Nilai rata-rata terendah terhadap aroma crackers diperoleh pada perlakuan P0 yaitu 5,67 disukai panelis sedangkan nilai rata-rata tertinggi di peroleh pada perlakuan P5 yaitu 6.40 disukai panelis. Menurut Winarno (2004), aroma dapat meningkatkan daya tarik konsumsi dan aroma makanan pada umumnya banyak menentukan kelezatan makanan serta citarasa bahan pangan itu sendiri.

\section{Tekstur}

Hasil sidik ragam menunjukkan bahwa penambahan tepung beras merah pregelatinisasi menujukan berpengaruh tidak nyata terhadap tekstur crackers $(\mathrm{P}>0,5)$ baik secara uji kesukaan (uji hedonik) maupun secara uji skoring. Tabel 5. menunjukkan bahwa nilai ratarata kesukaan panelis terhadap tekstur crackers berkisar antara 5,33 (agak disukai) panelis sampai dengan 5,87 (disukai) panelis.

Tabel 6 menunjukkan bahwa nilai rata-rata penerimaan terhadap tekstur uji skoring crackers berkisar antara 3,32 (agak renyah) sampai dengan 4,00 (renyah). 
Tabel 5. Nilai rata - rata Uji Hedonik Warna, Aroma, Tekstur, Rasa dan Penerimaan Keseluruhan Crackers

\begin{tabular}{|c|c|c|c|c|c|}
\hline \multirow{2}{*}{ Perlakuan } & \multicolumn{5}{|c|}{ Nilai rata - rata uji hedonik } \\
\hline & Warna & Aroma & Tekstur & Rasa & $\begin{array}{l}\text { Penerimaan } \\
\text { Keseluruhan }\end{array}$ \\
\hline P0 & $5.06 \pm 0,79 \mathrm{c}$ & $5.67 \pm 0,90 \mathrm{bc}$ & $5.33 \pm 0,81 \mathrm{a}$ & $5.33 \pm 0,81 \mathrm{c}$ & $5.33 \pm 0,81 \mathrm{a}$ \\
\hline P1 & $5.20 \pm 0,77 \mathrm{c}$ & $5.53 \pm 0,99 \mathrm{bc}$ & $5.40 \pm 0,82 \mathrm{a}$ & $5.80 \pm 0,86 \mathrm{bc}$ & $5.40 \pm 0,82 \mathrm{a}$ \\
\hline $\mathrm{P} 2$ & $5.73 \pm 0,70 \mathrm{~b}$ & $5.47 \pm 0,64 \mathrm{c}$ & $5.60 \pm 0,82 \mathrm{a}$ & $5.53 \pm 0,83 \mathrm{bc}$ & $5.60 \pm 0,82 \mathrm{a}$ \\
\hline P3 & $6.13 \pm 0,74 \mathrm{~b}$ & $6.07 \pm 0,88 \mathrm{abc}$ & $5.66 \pm 0,61 \mathrm{a}$ & $5.73 \pm 0,45 \mathrm{abc}$ & $5.86 \pm 0,67 \mathrm{a}$ \\
\hline $\mathrm{P} 4$ & $6.20 \pm 0,77 \mathrm{~b}$ & $6.20 \pm 0,86 \mathrm{ab}$ & $5.86 \pm 0,83 \mathrm{a}$ & $6.20 \pm 0,86 \mathrm{a}$ & $5.86 \pm 0,83 \mathrm{a}$ \\
\hline P5 & $6.73 \pm 0,45 \mathrm{a}$ & $6.40 \pm 0,82 \mathrm{a}$ & $5.73 \pm 0,88 \mathrm{a}$ & $6.07 \pm 0,59 \mathrm{ab}$ & $5.73 \pm 0,88 \mathrm{a}$ \\
\hline
\end{tabular}

Keterangan : Nilai rata - rata yang diikuti oleh huruf yang berbeda pada kolom yang sama menunjukkan berbeda nyata $(\alpha=0,05)$.

Tabel 6. Nilai rata-rata Uji Skoring Tekstur Crackers

\begin{tabular}{cc}
\hline \multirow{2}{*}{ Perlakuan } & Nilai rata - rata uji scoring \\
\cline { 2 - 2 } & Tekstur \\
\hline P0 & $3,26 \pm 0,68 \mathrm{a}$ \\
P1 & $3,33 \pm 0,72 \mathrm{a}$ \\
P2 & $3,67 \pm 0,90 \mathrm{a}$ \\
P3 & $3,93 \pm 0,59 \mathrm{a}$ \\
P4 & $4,13 \pm 0,92 \mathrm{a}$ \\
P5 & $4,00 \pm 0,85 \mathrm{a}$ \\
\hline
\end{tabular}

Keterangan : Nilai rata - rata yang diikuti oleh huruf yang berbeda pada kolom yang sama menunjukkan berbeda nyata $(\alpha=0,05)$.

Kriteria Tekstur : $5=$ sangat renyah; $4=$ renyah; $3=$ agak renyah; $2=$ tidak renyah; $1=$ sangat tidak renyah

\section{Rasa}

Hasil sidik ragam menunjukkan bahwa menunjukkan bahwa penambahan tepung beras merah pregelatinisasi sangat berpengaruh nyata terhadap rasa crackers $(\mathrm{P}<0,01)$. Tabel 5. menunjukkan bahwa nilai rata-rata kesukaan panelis terhadap rasa crackers berkisar antara 5,33 sampai dengan 6,20. Nilai rata-rata terendah terhadap tekstur crackers diperoleh pada perlakuan P0 yaitu 5,33 (agak disukai) sedangkan nilai rata-rata tertinggi tekstur crackers di peroleh pada perlakuan P5 yaitu 6,20 (disukai). Hal ini disebabkan penambahan tepung beras merah pregelatinisasi sehingga menghasilkan crackers yang memiliki rasa berbeda terhadap crackers pada umumnya Menurut Khasanah (2003) menyatakan bahwa rasa adalah faktor yang dinilai panelis setelah tekstur, warna dan aroma yang dapat mempengaruhi penerimaan produk pangan.

\section{Penerimaan Keseluruhan}

Hasil sidik ragam menunjukkan bahwa perbandingan tepung pregelatinisasi dengan terigu berpengaruh tidak nyata $(\mathrm{P}>0,5)$ terhadap penerimaan keseluruhan crackers. Terlihat pada Tabel 5. menunjukkan penerimaan keseluruhan terhadap crackers adalah suka. berkisar sebesar 5,33 (agak disukai) panelis sampai dengan 5,73 (disukai) panelis. Penerimaan keseluruhan crackers dipengaruhi oleh beberapa faktor seperti warna, aroma, tekstur dan rasa.

\section{KESIMPULAN DAN SARAN}

\section{Kesimpulan}

Berdasarkan hasil penelitian ini dapat disimpulkan sebagai berikut :

1. Perbandingan tepung beras merah pregelatinisasi dengan terigu berpengaruh sangat nyata terhadap kadar air, kadar protein, aktivitas antioksidan dan total fenol, dan uji hedonik pada warna, rasa, aroma. 
2. Perlakuan perbandingan $50 \%$ tepung beras merah pregelatinisasi dengan 50 $\%$ terigu menghasilkan crackers dengan karakteristik terbaik yaitu: kadar air 1,15\%, kadar abu 1,73\%, kadar protein 10,26\%, aktivitas antioksidan $45,17 \%$, total fenol 158,83 GAE/g, dengan aroma agak disukai, dan warna, rasa, penerimaan keseluruhan disukai, dan memiliki tekstur renyah.

\section{Saran}

Untuk pembuatan crackers tepung beras merah pregelatinisasi sebaiknya menggunakan perbandingan 50\% tepung beras merah pregelatinisasi dan $50 \%$ terigu sehingga mendapatkan perlakuan terbaik.

\section{DAFTAR PUSTAKA}

Anonimus 1995.(SNI 013741 1995)

Anonimus 1990. Produk Andalan Sektor Industri. Jakarta

APTINDO. Asosiasi Produsen Tepung Terigu Indonesia.2016. An Overview of Indonesian Wheat Flour Industry and Wheat Flour Quality. Jakarta. APTINDO

Artama 2001. Pemanfaatan Tepung Ikan Lemuru (Sardinella longiceps) Untuk Meningkatkan Mutu Fisik dan Nilai Gizi Crackers. Tesis. Program Pasca Sanjana. Institut Pertanian Bogor. Bogor.

Novilia,C. 2017. Kandungan Gizi, Total Fenol dan Aktivitas Antioksidan Snack Bar Takokak. Departemen gizi masyarakat fakultas ekologi manusia. IPB. Bogor

Dykes L, L.W Rooney. 2006. Sorghum and Millet Phenols and Antioxidants. Cereal Science. 44 (3):236-251.

Gomez dan Gomez. 1995. Reviews of the Progress of Diary Science: Genetics of Lactic Acid Bacteria. Journal of Dairy Review 48: 363 - 376.

Juliano, B.O. and D.B. Bechtel, 1985. Rice Chemistry and Technology 2nd. St. Paul: Am. Assoc. Cereal Chem
Karina, T. 2017. Pengaruh Perbedaan Proporsi Tepung Ubi Jalar Ungu Dan Tepung Beras Merah Terhadap Sifat Flakes. Skripsi. FTP. Universitas Katolik Widya Mandala Surabaya.

Khasanah, U. 2003. Formulasi, Karakteristik Fisiko- Kimia dan Organoleptik Produk Makanan Sarapan Ubi Jalar (Sweet Potato Flakes).Skripsi. IPB. Bogor.

Manley, D. J. R. 1983. Technology of Biscuit, Crackers And Cookies. Ellis Horwood Limited, Chicester..Univ. Sapientiae, Alimentania, 82

Meilgaard, M., G.V. Civille, dan B.T. Carr. 1999. Sensory Evaluation Technique. CRC Press. New York.

Nurdjanah Siti. 2011. Karakteristik Biskuit Coklat Dari Campuran Tepung Pisang Batu (Musa balbisiana colla) Dan Tepung Terigu Pada Berbagai Tingkat Substitusi. Jurnal. Jurusan Ilmu Dan Teknologi Pangan. Universitas Lampung. Lampung http://jurnal.fp.unila.ac.id/index.p hp/JTHP/article/view/44

(November 2018)

Paini Sri W. 2014. Pengaruh Perbandingan Warna Pigmen Beras Organik Terhadap Aktivitas Antioksidan. FTP. Universitas Katolik Widya Mandala Surabaya.

Passos, M.E.A., C.F.F, Moreira., M.T.B, Pacheco., I,Takase., M.L.M, Lopes., V.L, Valente Mesquita. 2013. Proximate and Mineral Composition of Industrialized Biscuits. Food Science and Technology, Campinas, 33(2):323-3331

Rohaya, M.S., M.Y, Maskat. dan A.G, Ma'aruf. (2013). Rheological properties of different degree of pregelatinized rice flour batter. Sains Malaysiana 42: 1707-1714

Soesanto, T. dan B. Saneto, 1994. Teknologi Pengolahan Hasil Pertanian. Bina Ilmu, Surabaya. 
Suardi, D. 2005. Potensi Beras Merah Untuk Peningkatan Mutu Pangan. Jurnal Penelitian dan Pengembangan Pertanian. Vol 24, No.3, 2005. http//www.pustaka -deptan.go.id (November 2018).

Suliartini, S. N. W., R.S Gusti, W Teguh , Muhidin. 2011. Pengujian Kadar Antosianin Padi Gogo Beras Merah Hasil Koleksi Plasma Nutfah Sulawesi Tenggara. Crop Agro Vol. 4 (2): 43-48.

Tamdani, I. D. 2012. Substitusi Tepung Terigu dengan Tepung Beras Merah Pregelatinisasi dalam pembuatan cookies.Undergraduate thesis, Widya Mandala Catholic University Surabaya.
Vichapong, J, Sookserm, M, Srijesdaruk, V, Swatsitang, P, Srijaranai, S. 2010. High performance liquid chromatographic analysis of phenolic compounds and their antioxidant activities in rice varieties. LWT-Food Science and Technology.43(9):1325-1330

Winarno, F.G., 2002, Kimia Pangan dan Gizi, Gramedia Pustaka Tama, Jakarta

Yessica M.W. 2013. Sifat Fisikokimia Tepung Pregelatinisasi Beras Merah Dan Ketan Hitam Dengan Variasi Waktu Pengukusan. Skripsi. Fakultas Teknologi Pertanian. Universitas Katolik Widya Mandala. Surabaya 